\title{
Experimental investigation of the control of bacterial community composition in macrofaunal burrows
}

\author{
Roberta L. Marinelli ${ }^{1, *}$, Charles R. Lovell ${ }^{2}$, Stuart G. Wakeham ${ }^{3}$, \\ David B. Ringelberg ${ }^{4, * *}$, David C. White ${ }^{5}$ \\ ${ }^{1}$ Chesapeake Biological Laboratory, University of Maryland Center for Environmental Science, PO Box 38, Solomons, \\ Maryland 20688, USA \\ ${ }^{2}$ Department of Biological Sciences, University of South Carolina, Columbia, South Carolina 29208, USA \\ ${ }^{3}$ Skidaway Institute of Oceanography, 10 Ocean Science Circle, Savannah, Georgia 31411, USA \\ ${ }^{4}$ US Army Environmental Research and Development Center, 3909 Halls Ferry Road, Vicksburg, Mississippi 39180, USA \\ ${ }^{5}$ Center for Environmental Biotechnology, 10515 Research Drive, Suite 300, Knoxville, Tennessee 37932, USA
}

\begin{abstract}
The burrows and tubes of infauna are complex and dynamic systems that promote significant heterogeneity in the ecological and geochemical properties of benthic systems. We experimentally evaluated the extent to which behaviors of macrofauna, including ventilation activity, the residence times of tubes in sediments and tube composition, influence the development and succession of microbial communities which line macrofaunal burrows (i.e. the burrow microbial biofilm). Our experiments used a burrow mimic system, which allowed manipulation of some biological and environmental factors while holding other factors constant. The biofilm microbial community was assessed using phospholipid fatty acid (PLFA) analysis, a sensitive measure of microbial biomass and a significant tool in the identification of some taxonomic and functional groups of microorganisms in marine systems. Results suggest that the burrow mimics supported the development of microbial assemblages with phospholipid signatures that were both similar to those found in natural burrows and responsive to experimental manipulation. Burrow mimic composition significantly affected PLFA signatures, within the range of compounds and concentrations observed in natural systems. Tubes that were coated with an organic polymer were characterized by lower microbial biomass than uncoated tubes and also exhibited a substantially different PLFA signature. The residence time of tube mimics in sediments also affected the PLFA signature. Tubes with a longer residence time were characterized by higher microbial biomass, and a distinct anaerobe signature, relative to tube mimics having shorter residence times. Thus, a distinct successional sequence was observed. Surprisingly, irrigation frequency, i.e. the rate at which burrows are renewed with fresh, oxic overlying water and rid of metabolic byproducts and other solutes from the host organism and surrounding sediments, had minor effects on PLFA signature within the burrow biofilm. Our results suggest that the properties of the burrow microenvironment exert fundamental controls on microbial community composition in burrow biofilms and are likely to influence biogeochemical processes over short length scales in nearshore systems.
\end{abstract}

KEY WORDS: Phospholipid fatty acids · Microorganisms · Polychaetes · Bioturbation · Irrigation Resale or republication not permitted without written consent of the publisher

\footnotetext{
*E-mail: marinelli@cbl.umces.edu

** Present address: United States Army Corps of Engineers, Cold Regions Research and Engineering Laboratory (USACE, CRREL), 72 Lyme Road, Hanover, New Hampshire 03755 , USA
}

\section{INTRODUCTION}

The burrows and tubes of sedimentary infauna form an ecologically dynamic environment where biological and chemical interactions are greatly enhanced rela- 
tive to surrounding sediments. Burrows and tubes provide a surface for microbial colonization that is distinct from the surrounding sediment. In addition, ventilation of burrows creates sharp gradients in solute concentrations along the burrow-sediment interface (e.g. Aller \& Yingst 1978, Aller 1980, Boudreau \& Marinelli 1994), which can result in high material flux (Kristensen 1984, Aller \& Yingst 1985, Kristensen et al. 1985, Huttel 1990, Marinelli 1992, Martin \& Banta 1992). These attributes facilitate the development of rich microbial communities where activity and biomass are elevated relative to surrounding sediment (Aller \& Yingst 1978, Kristensen et al. 1985, 1991b, King 1986, Dobbs \& Guckert 1988a,b). Burrows and tubes also provide physical refuges for small infauna against predation/disturbance (Woodin 1982, 1984), and in some cases, chemical refuges against the highly anoxic sediments of nearshore environments (Marinelli 1994). The refuge effect and the rich microbial environment appear to promote aggregation of metazoans, including macrofauna (Marinelli 1994), meiofauna (Aller \& Aller 1986, Meyers et al. 1987, 1988) and protozoans (Fenchel 1996).

Studies of tube and burrow biogeochemistry are united in their findings that the tube interface has a distinct microbial biofilm community and is a significant focus of oxidation-reduction reactions. However, these microbial communities, and the diagenetic processes they facilitate, vary substantially among macrofaunal species and habitats. For example, studies by Aller \& Yingst (1978) and Aller et al. (1983) show differences among oxidation-reduction processes and bacterial compositions in the burrows of the onuphid polychaete Onuphis, the crustacean Upogebia and the terebellid polychaete Amphitrite ornata. The sources of this variation may result from the interplay among complex environmental variables, including: (1) physicochemical properties of dwellings, which vary widely in porosity, permeability and chemical composition (Aller \& Yingst 1978, Aller 1983); (2) the types of exudates released from the burrow- or tube-building host (e.g. dissolved organic substances [Scott 1976, Schottler et al. 1983], or halogenated secondary metabolites [King 1986, Woodin et al. 1987, 1993, Jensen et al. 1992, Steward et al. 1996]); and (3) differences in sedimentary and water column environments in which the macrofauna live (organic-rich versus organic-poor sediments, water column nutrient concentrations [Kristensen 1984, Kristensen et al. 1985]).

Transient processes related to the biology and ecology of the host organisms may also influence microbial communities and biogeochemical processes in macrofaunal dwellings. For example, ventilation or irrigation behavior is periodic, with internal or environmental triggers (Wells 1949, Wells \& Dales 1951, Mangum 1964, Kristensen 1983, Woodin \& Marinelli
1991). This periodic behavior influences the supply of oxidants and removal of metabolites from bacteria along the burrow lining and surrounding sediment (Aller et al. 1983, Kristensen 1984, Woodin \& Marinelli 1991, Forster \& Graf 1992, 1995). As a result, the composition of microbial communities on the inner and outer tube surface, and their attendant influences on burrow biogeochemistry, may vary greatly with irrigation behavior (Boudreau \& Marinelli 1994, Mayer et al. 1995, Marinelli \& Boudreau 1996). The residence time of burrows and tubes in sediments also is a potentially important transient feature influencing burrow microbial properties. Many infauna emigrate and build new burrows or tubes on the order of days to weeks (e.g. Krager \& Woodin 1993, Marinelli 1992). While the frequency of emigration activity is not known for most species, it may be caused by food limitation or densitydependent interactions (R. Marinelli unpubl. data). Emigration imparts significant disruption to sediments and porewaters, and greatly enhances sedimentseawater exchange (Marinelli 1992). The new tube also presents a new surface for microbial colonization and represents the initial stage of the development of, and the onset of successional events for, the microbial community that lines the inner and outer surfaces of macrofaunal dwellings. Hence, some variation in the biogeochemical properties of burrows and tubes may be related to successional changes in the microbial community composition over time.

In this paper, we present experimental evidence that behaviors of macrofauna, including residence times of tubes in sediments and the composition of the tubes, influence the development and succession of microbial communities which inhabit macrofaunal burrows walls. Our experimental system employs burrow mimics, embedded in natural sediments, which have physical properties that are nearly identical to those found in many natural burrows. Moreover, these mimics develop microbial biofilms which have similar properties to natural biofilm communities found in macrofaunal tubes, and therefore provide an excellent system for examining processes that control microbial activity and succession in dynamic marine environments.

Sensitive methods are required for analysis of community species composition and dynamics from small biofilm samples. Phospholipid fatty acid (PLFA) analysis was employed for the present study because it offers a number of significant advantages for the examination of biofilm development and successional processes (White 1983, 1988, Guckert et al. 1985, Rajendran et al. 1992, Findlay \& Dobbs 1993). Phospholipids are not used as reserve polymers and turn over rapidly after cell death, providing a sensitive measure of viable microbial biomass (White 1983, 1988). Analysis of membrane-bound (ester-linked) 
PLFAs after their conversion to fatty acid methyl esters assures that only PLFAs derived from viable organisms are included in the analysis. PLFAs can be extracted from small samples, and large sample sets can be easily and reproducibly analyzed, providing a sensitive and quantitative means for studying in situ microbial biomass and community composition. Although the method does not allow complete identification or quantification of all microbial groups in complex communities (see Haak et al. 1994), it has proven very useful in the determination of microbial biomass and identification of some taxonomic and functional groups of microorganisms in environmental samples (Federle et al. 1986, Vestal \& White 1989, Tunlid \& White 1992, Findlay \& Dobbs 1993).

\section{MATERIALS AND METHODS}

Preparation of burrow mimics. Burrow mimics were constructed from sheets of Magna Nylon membrane $(0.45 \mu \mathrm{m}$ pore size). Each sheet was rolled to form a cylinder that was $1 \mathrm{~cm}$ in diameter (ID), $15 \mathrm{~cm}$ in length and 3 sheets $(0.3 \mathrm{~mm})$ in thickness. These 'artificial burrows' were placed in 1 dram shell vials $(15 \times$ $45 \mathrm{~mm}$ ) that provided an anchor for placement in cores. Burrow mimics were positioned centrally and singly in small sections of PVC pipe (5 cm ID $\times 15 \mathrm{~cm}$ length) which were sealed on 1 end with heavy plastic. Subsequently, freshly collected sediments from the intertidal zone of the Skidaway River were added gradually to cores until the sediment was flush with the top of the core. During sediment addition, the openings of the burrow mimics were covered so that no sediment could enter the burrow interior. The shell vial 'anchor' surrounded the bottom $4.5 \mathrm{~cm}$ of the tube, but the upper $10.5 \mathrm{~cm}$ of membrane was in direct contact with surrounding sediment. Upon completion of sediment addition, each mimic protruded slightly (approximately $0.5 \mathrm{~cm}$ ) above the sediment surface. Cores were placed in flowing seawater and allowed to stabilize overnight. Only the portion of the tube that extended from the lip of the vial to the sediment surface was analyzed for PLFA biomass and composition.

Experiments. While our goal was to examine the effects of transient processes on microbial biofilm dynamics, we also recognized the importance of tube composition to biogeochemical processes, and wanted to evaluate 'composition' in the context of irrigation activity and tube residence time. The significance of these processes was examined in 2 separate experiments. In December 1994, we conducted a 2-factor experiment that examined the influence of tube composition and irrigation frequency on microbial community composition, as defined by PLFA analysis. In this experiment, we altered tube composition by coating a subset of burrow mimics with a $0.8 \%$ solution of Gelrite, a commercially available exopolymer derived from the bacterium Sphingomonas elodea. We manipulated irrigation frequency using the 'artificial irrigation system' described in Marinelli \& Boudreau (1996). In this system, irrigation of burrow mimics is accomplished by suspending a small glass tube in each burrow mimic. The glass tube is connected (by flexible tubing) to a header tank which is filled according to a specified irrigation cycle. As the header tank is filled, water flows through the glass tube to the base of the mimic and then flows up along the sides of the mimic wall (Fig. 1). Two irrigation cycles, chosen to reflect the range of irrigation behaviors observed in natural organisms (Wells 1949, Wells \& Dales 1951, Mangum 1964, Kristensen 1983, Woodin \& Marinelli 1991) were tested. 'Discontinuous Irrigation' consisted of $5 \mathrm{~min}$ of irrigation followed by $55 \mathrm{~min}$ of quiescence. 'Continuous Irrigation' mimics were constantly ventilated. Thus, a total of 4 'treatments' was established, each containing 5 independent replicates: Discontinuous Irrigation + Uncoated Mimics; Discontinuous Irrigation + Coated Mimics; Continuous Irrigation + Uncoated Mimics; Continuous Irrigation + Coated Mimics. In this experiment, sediments surrounding the cores were fine-grained muds that were homogenized but not sieved prior to use in experiments. The burrow mimics, embedded in sediment cores, were irrigated according to the specified frequencies for $7 \mathrm{~d}$. Subsequently, the

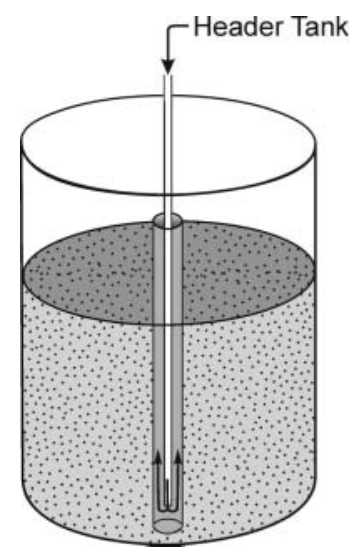

Fig. 1. Schematic of the burrow mimic system. Burrow mimics were composed of rolled sheets of nylon membrane which were $15 \mathrm{~cm}$ in length, $1 \mathrm{~cm}$ in diameter and 3 sheets $(0.3 \mathrm{~mm})$ in thickness. Mimics were placed in PVC pipes $(15 \mathrm{~cm}$ in length, $5 \mathrm{~cm}$ in diameter) which were closed at the base. Irrigation was accomplished by suspending a small glass tube in each mimic. The tube was connected to a header tank which was filled at a specified frequency. As the header tank was filled, water would flow through the tube to the base of the mimic and then up along the sides of the mimic wall 
mimics were removed from sediments, and rinsed gently in $0.2 \mu \mathrm{M}$ filtered seawater. The portion of the mimic that protruded above the sediment, and the lower $5 \mathrm{~cm}$ that was confined by the shell vial, were removed and discarded. Mimics were stored at $-80^{\circ} \mathrm{C}$ until PLFA analyses could be performed. The experiment was conducted in the dark (to discourage benthic diatom growth), and the seawater temperature was $16^{\circ} \mathrm{C}$.

In Expt 2 (June 1995), we examined the effect of irrigation frequency, and the effect of residence time of burrow mimics in sediments, on microbial biofilm community development. As burrow mimic composition was tested in the previous experiment and its inclusion as a third factor would generate a large number of replicates, this factor was not evaluated in Expt 2 . Uncoated burrow mimics were prepared as described above and surrounded with a muddy sand mixture that was homogenized but not sieved. Tubes were allowed to equilibrate for $1 \mathrm{~d}$ prior to initiation of the experiment. Twenty mimics were established, with 10 designated for 'Discontinuous Irrigation' treatment and 10 designated for 'Continuous Irrigation', treatment, as defined above. To assess 'residence time', tubes were allowed to remain in sediments for 2 or $6 \mathrm{wk}$. These time periods represent a range of residence time of established burrows in sediments. Some organisms move every few days (Krager \& Woodin 1993, Marinelli 1994) whereas other organisms establish more permanent dwellings (Table 31 in Fauchald \& Jumars 1979). For motile organisms, the frequency of movement may not be intrinsic to the organism, but rather externally triggered by disturbances of physical or biotic origin (Krager \& Woodin 1993).

A total of 4 treatments was established, each with 5 independent replicates: Discontinuous Irrigation + 2 wk Mimics; Discontinuous Irrigation + $6 \mathrm{wk}$ Mimics; Continuous Irrigation +2 wk Mimics; Continuous Irrigation +6 wk Mimics. As in the previous experiment, cores were maintained in darkness. During the experiment, the seawater temperature was $30^{\circ} \mathrm{C}$. At termination of each phase of the experiment, mimics were removed from sediment and rinsed gently in $0.2 \mu \mathrm{m}$ filtered seawater. The portion of the mimic that protruded above the sediment, and the lower $5 \mathrm{~cm}$ that was confined by the shell vial, were removed and discarded. Mimics were stored at $-80^{\circ} \mathrm{C}$ until PLFA analyses could be performed.

Assessment of burrow mimic physical properties: To assure that the Magna nylon membrane possessed diffusive properties similar to those of natural burrows, the porosity of the membrane (volume pore space/total volume) was assessed by determination of membrane volume and wet versus dry mass. The permeability of the membrane to solute diffusion was assessed accord- ing to Aller (1983). In this method, a membrane is placed between 2 reservoirs containing solutes of known but different concentration, thereby setting up a diffusion gradient across the membrane (Fig. 2). The change in solute concentration over time in each reservoir represents the flux across the membrane. If the free solution diffusion coefficient of the solute is known, and the flux across the membrane is measured, then the 'diffusive hindrance' (sensu Aller 1983) of the membrane can be calculated.

Two solutions of similar ionic strength were prepared for the reservoirs. The large outer reservoir contained a solution of $0.5 \mathrm{M} \mathrm{KNO}_{3}+0.05 \mathrm{M} \mathrm{Na}_{2} \mathrm{SO}_{4}$. The inner, small reservoir contained $0.5 \mathrm{M} \mathrm{KNO}_{3}+0.05 \mathrm{M}$ $\mathrm{KCl}$. The change in concentration of $\mathrm{Cl}^{-}$in each reservoir was measured by periodic sampling of each vessel over several days. Water levels in the reservoirs were kept at the same height, to avoid enhanced solute exchange driven by pressure gradients. The permeabilities of a triple layer of uncoated membrane and a triple layer of coated membrane were determined in separate experiments. Chloride concentrations were determined by $\mathrm{AgNO}_{3}$ titration.

According to Aller (1983), the relationship used to examine the change in concentration over time in the reservoirs and the effect of the membrane on the chloride flux is:

$$
\ln \frac{C_{1(0)}-C_{2(0)}}{C_{1(t)}-C_{2(t)}}=\frac{\phi A D}{L \theta^{2}} \frac{1}{V_{1}}+\frac{1}{V_{2}} t
$$
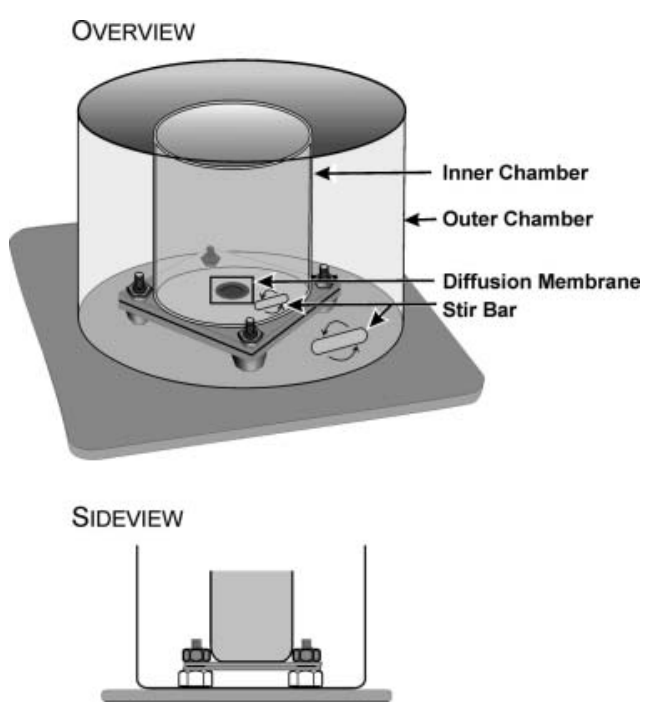

Fig. 2. Schematic of the diffusion cell system. Sections of uncoated or coated nylon membrane were placed within the test section between the inner and outer cells, and sealed with small rubber o-rings. The hindrance to diffusion posed by the membrane was measured by sampling the build-up or depletion of solutes in the large versus small reservoir over time and using the concentration information in Eq. (1) 
where $C_{1}, C_{2}=$ concentrations (M) in Reservoirs 1 and 2 , respectively, $t=$ time $(\mathrm{h}), \phi=$ porosity of the membrane, $A=$ area of exposed membrane $\left(\mathrm{cm}^{2}\right), D=$ free solution diffusion coefficient $\left(\mathrm{cm}^{2} \mathrm{~h}^{-1}\right), L=$ thickness of membrane (cm), $\theta=$ tortuousity and $V_{1}, V_{2}=$ volume of Reservoirs 1 and 2, respectively $\left(\mathrm{cm}^{3}\right)$. The ratio $\phi / \theta^{2}$ represents the hindrance effect of the membrane on the diffusion coefficient.

Lipid analyses: Lipids were extracted using a modified Bligh \& Dyer (1959) extraction procedure. Burrow mimics were placed in methanol:chloroform:50 mM phosphate buffer $\mathrm{pH} 7.4$ with a final solvent volume ratio of 2.5:1.25:1, then sonicated for several min, allowed to stand overnight and finally centrifuged (30 min at $2000 \mathrm{rpm}$ ). The supernatant was transferred to a separatory funnel, and additional chloroform and water were added to separate the solution into 2 phases (final solvent volume ratio was 1:1:0.9 for chloroform:methanol:water/buffer). Total lipid extracts were split into general lipid classes (neutral, glyco- and polar lipids) using silicic acid chromatography. Fatty acid methyl esters (FAMEs) were prepared from the polar lipid fraction by mild alkaline methanolic transesterification as reported by Guckert et al. (1985). Compounds were separated for quantification using capillary gas chromatography with flame ionization detection, using C19:0 as an internal injection standard. For Expt 1 (effects of irrigation and tube composition), samples were run through a Hewlett-Packard 6890 gas chromatograph (GC) equipped with a J \& W DB-1 methyl silicone column, with a 1 min spitless injection time and an injection temperature of $270^{\circ} \mathrm{C}$. For Expt 2 (effects of irrigation and residence time), samples were run through a Carlo Erba GC 6000, equipped with a Restek methyl silicone column, but with cold injection. For both GCs, the oven temperature was programmed from 100 to $150^{\circ} \mathrm{C}$ at $10^{\circ} \mathrm{C} \mathrm{min}{ }^{-2}$ and then to $280^{\circ} \mathrm{C}$ at $3^{\circ} \mathrm{min}^{-1}$ with a $5 \mathrm{~min}$ isothermal hold. The detector temperature was $290^{\circ} \mathrm{C}$ for the Hewlett Packard GC and $310^{\circ} \mathrm{C}$ for the Carlo Erba GC). Bacterial fatty acid double-bond position and geometry were confirmed using GC/MS analysis of the dimethyl disulfide adducts of the monounsaturated polar FAMEs as described in Nichols et al. (1986). Results are reported using the omega reference nomenclature, which describes the number of carbons (followed by a colon), then the number of double bonds and finally the position of the double bond closest to the first $(\omega)$ carbon (and opposite the carboxylic acid

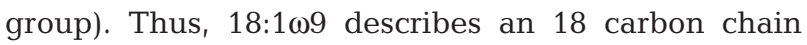
with 1 double bond occurring at the 9th carbon atom.

Statistical analyses: Analysis of PLFA data was performed using analysis of variance (ANOVA) followed by Tukey's studentized range test (if appropriate) and multivariate cluster analysis. A subset of 4 PLFAs was selected for ANOVA by treatment (i.e. composition, irrigation frequency, residence time), using the concentration data only. These compounds were selected

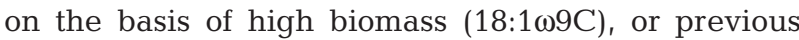
reports of their association with sulfate-reducing bacteria (10me16:0 and i17:167c, cy17) (Guckert et al. 1985, Rajendran et al. 1992, Vainshtein et al. 1992, Findlay \& Dobbs 1993). This more limited approach avoids multiple testing problems and the possibility of Type I errors, i.e. emergence of a significant finding by chance only. Significance levels for the ANOVA were adjusted according to the Bonferroni procedure, with an overall significance level of 0.013. Statistical analyses were conducted using SAS or Fortran 77.

Materials. All solvents used in PLFA analyses were GC grade, either from Burdick and Jackson or Fisher Scientific. Standards and derivitizing reagents were purchased from Supelco, Nu Chek Prep and Pierce Chemical. Magna Nylon membranes were obtained from Micron Separations. GELRITE was obtained from Merck.

\section{RESULTS}

\section{Assessment of burrow mimic physical properties}

The nylon membranes used as artificial tube structures in these experiments were highly permeable to solute diffusion, as indicated by the relative change in chloride concentration over time in the small and large reservoirs (Fig. 3). Porosity of the nylon membrane, whether uncoated or coated, was $76 \%$, well within the

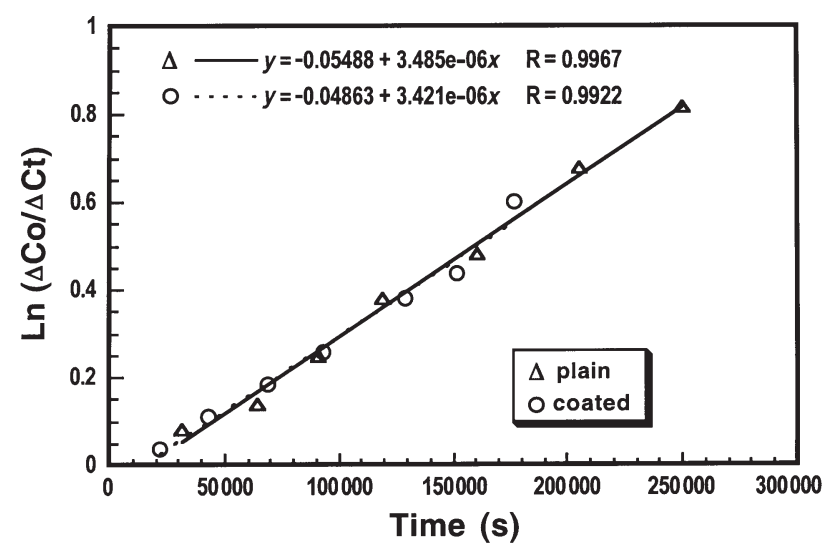

Fig. 3. Change in chloride concentration versus time in diffusion cell reservoirs in experiments examining the diffusion across coated and uncoated burrow mimic membranes. There is essentially no effect of coating on the diffusive hindrance posed by the membrane, therefore differences in lipid signature could be ascribed to chemical properties of the membrane 
range of animal tube porosities measured by Aller (1983) (0.62 to 0.91). The calculated hindrance to diffusion $\left(\phi / \theta^{2}\right)$ posed by the membrane differed slightly for the uncoated versus coated membrane. For the uncoated membrane, the diffusive hindrance was 0.27 , whereas for the Gelrite-coated membrane, the diffusive hindrance was 0.24 . These values also fall within the range of quantities determined by Aller (1983) ( 0.12 to 0.37 ). Thus, the physical properties of the burrow mimics were quite similar to those of natural burrows and tubes, demonstrating that the mimics provide an excellent analog to natural burrow systems.

\section{Development of the burrow microbial biofilm}

The burrow biofilm assessed in the experiments includes the populations of microbes on the inner and outer surface of the mimic. While microbes could not necessarily migrate across the membrane surface, the mimic communities were linked via the oxidationreduction reactions and diffusion gradients across this unique diagenetic environment. The burrow mimics supported development of microbial assemblages with phospholipid signatures that were similar in terms of relative abundance and composition to those found in natural burrows (Steward et al. 1996), and responsive to experimental manipulation. Burrow mimic microbial communities were very complex, containing ap- proximately 40 identifiable PLFAs (Tables 1 \& 2). In all experimental treatments, representatives of the major classes of PLFAs were present (Tables 1 \& 2, Fig. 4A,B). This community complexity is comparable to that of natural marine sediment samples (Findlay \& White 1983, Dobbs \& Guckert 1988a,b), and the major PLFA groups recovered from burrow mimics corresponded closely to those from natural tubes and burrows (Steward et al. 1996). These similarities include microbial communities rich in monounsaturated and saturated fatty acids with chain lengths of 14 to 20 carbon atoms, and polyunsaturated fatty acids in lesser abundance than monounsaturates (Tables 1 \& 2, Fig. 4B). Low quantities of polyunsaturated and high quantities of monounsaturated PLFAs indicate biofilms dominated by bacteria (Smith et al. 1986, Dobbs \& Guckert 1988a, Findlay et al. 1990) as has been observed in natural burrows and tubes. Polyunsaturated fatty acids, indicative of eukaryotes, have been found at higher levels in some natural burrows (Notomastus lobatus and Balanoglossus aurantiacus, see Steward et al. 1996), but not in tubes that extend above the sediment-water interface (Branchioasychis americana, see Steward et al. 1996), as the burrow mimics did. Extension of the tube above the sediment water interface likely impedes sediment (and benthic microalgal) transport into the tube, thus decreasing the eukaryotic presence (Steward et al. 1996). Other groups represented in the burrow mimics, and also

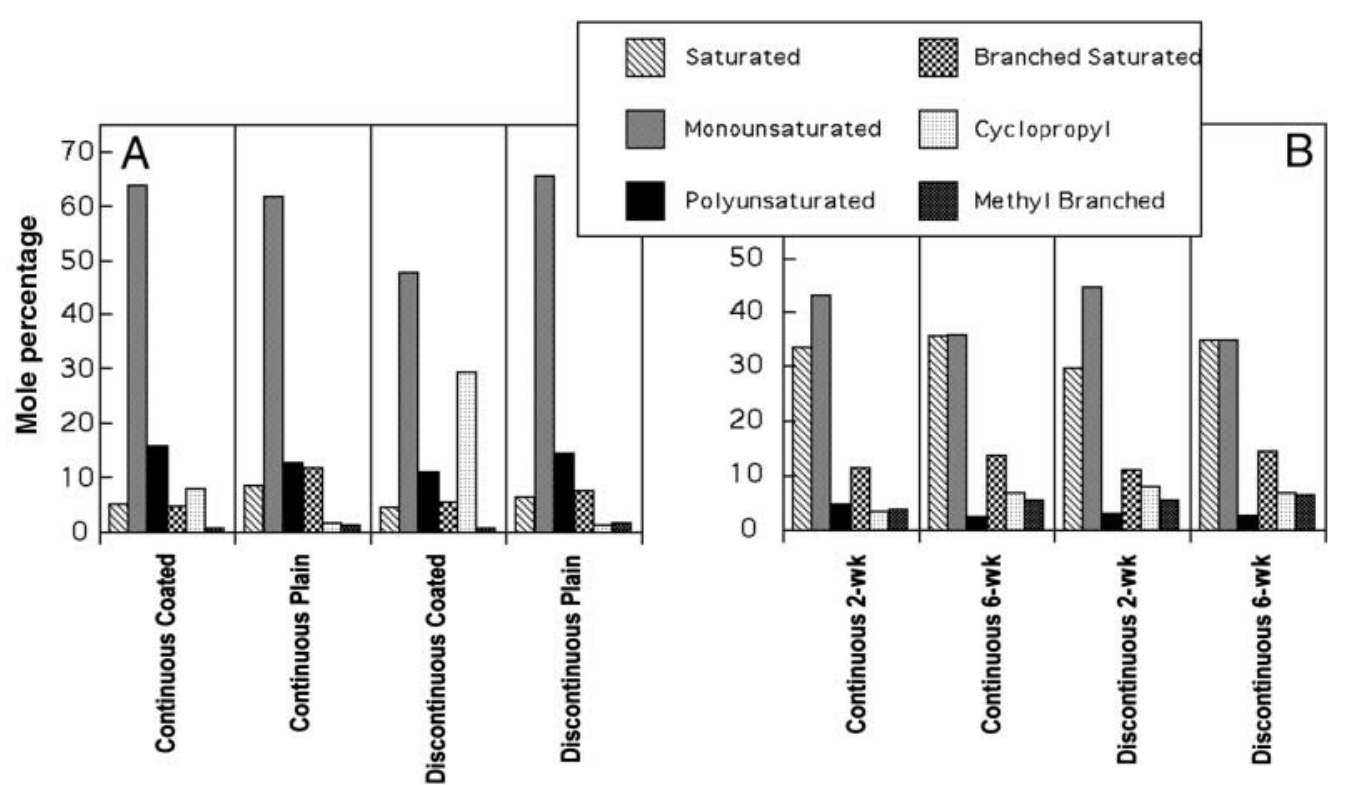

Fig. 4. Major classes of phospholipid fatty acids found in burrow mimics subjected to experimental manipulation. (A) Lipid classes in mimics from Expt 1 which examined the effects of mimic composition (uncoated vs coated) and irrigation frequency (continuous vs discontinuous). (B) Lipid classes in mimics from Expt 2, which examined the effect of tube residence time (2 wk vs 6 wk) and irrigation frequency (continuous vs discontinuous). In both experiments, the lipid classes and signatures were consistent with the range and concentrations of compounds found in natural burrows (e.g. Steward et al. 1996) 
Table 1. Phospholipid fatty acid (PLFA) values presented as moles per unit area and as mol\% of total PLFA for burrow mimics from Expt 1. PLFA shown are $>0.1$ mol\% of fatty acids in the profiles. $\Sigma$ SFA: sum of saturated PLFA; $\Sigma$ MFA: sum of monounsaturated PLFA; $\Sigma$ PFA: sum of polyunsaturated PLFA; $\Sigma$ BFA: sum of all terminally branched saturated PLFA; $\Sigma$ Cy: sum of cyclopropyl PLFA; LmeBFA: sum of methyl-branched saturated PLFA; Cy/MUFA: ratio of cyclopropyl PLFA to the MFA precursor; Trans/cis: ratio of trans to cis isomers of a given PLFA. Values presented are means. Standard deviations in parentheses

\begin{tabular}{|c|c|c|c|c|c|c|c|c|}
\hline & \multicolumn{4}{|c|}{ Continuous irrigation } & \multicolumn{4}{|c|}{ Discontinuous irrigation } \\
\hline & _ Coated & $\overline{\mathrm{mol} \%}$ & Irrigation & $\mathrm{mol} \%$ & \multicolumn{2}{|c|}{ _ Coated —— } & 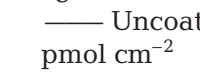 & $\mathrm{ed}-\mathrm{mol} \%$ \\
\hline \multicolumn{9}{|l|}{ Saturated } \\
\hline 14:0 & $0.60(0.57)$ & 0.83 & $4.46(6.31)$ & 2.19 & $1.10(0.89)$ & 0.79 & $1.22(0.50)$ & 0.82 \\
\hline $15: 0$ & $0.77(1.31)$ & 1.06 & $3.65(5.49)$ & 1.80 & $1.65(2.03)$ & 1.18 & $1.47(1.86)$ & 0.99 \\
\hline $17: 0$ & $1.33(0.88)$ & 1.84 & $8.43(5.28)$ & 4.15 & $2.41(2.2)$ & 1.74 & $6.25(4.79)$ & 4.2 \\
\hline $20: 0$ & $1.01(0.71)$ & 1.41 & $0.99(0.58)$ & 0.49 & $0.82(0.56)$ & 0.59 & $0.93(0.55)$ & 0.63 \\
\hline$\Sigma$ SFA & 3.71 & 5.14 & 17.53 & 8.62 & 5.97 & 4.30 & 9.87 & 6.63 \\
\hline \multicolumn{9}{|c|}{ Monounsaturated } \\
\hline $16: 1 \omega 5 \mathrm{c}$ & $0.27(0.48)$ & 0.38 & $1.09(1.12)$ & 0.54 & $0.40(0.7)$ & 0.29 & $0.71(0.81)$ & 0.48 \\
\hline $16: 1 \omega 7 \mathrm{c}$ & $6.23(6.77)$ & 8.64 & 27.05 (32.95) & 13.31 & $10.25(8.44)$ & 7.38 & $17.53(18.06)$ & 11.78 \\
\hline $16: 1 \omega 7 t$ & $0.20(0.31)$ & 0.27 & $1.00(1.82)$ & 0.49 & $0.49(1.11)$ & 0.36 & $0.68(1.06)$ & 0.46 \\
\hline $16: 1 \omega 9 c$ & $0.84(0.57)$ & 1.16 & $7.57(10.94)$ & 3.73 & $2.29(3.6)$ & 1.65 & $2.21(2.06)$ & 1.49 \\
\hline $17: 1$ & $0.54(0.13)$ & 0.75 & $0.63(0.50)$ & 0.31 & $0.33(0.22)$ & 0.24 & $0.75(0.42)$ & 0.51 \\
\hline i17: $1 \omega 7 \mathrm{c}$ & $0.15(0.21)$ & 0.21 & $0.75(0.74)$ & 0.37 & $0.14(0.3)$ & 0.1 & $0.45(0.64)$ & 0.3 \\
\hline $18: 1 \omega 5 \mathrm{c}$ & $0.23(0.37)$ & 0.32 & $0.69(0.25)$ & 0.34 & $0.24(0.3)$ & 0.17 & $0.79(0.62)$ & 0.53 \\
\hline $18: 1 \omega 7 \mathrm{C}$ & $11.79(6.81)$ & 16.35 & $37.10(13.29)$ & 18.25 & $24.40(23.7)$ & 17.57 & $36.71(17.97)$ & 24.66 \\
\hline $18: 1 \omega 7 t$ & $0.29(0.65)$ & 0.4 & $1.19(0.82)$ & 0.58 & $0.63(1.13)$ & 0.45 & $1.16(0.83)$ & 0.78 \\
\hline $18: 1 \omega 9$ & $25.04(9.63)$ & 34.75 & $47.57(19.18)$ & 23.41 & $26.70(14.84)$ & 19.22 & 35.95 (18.5) & 24.15 \\
\hline $20: 1 \omega 9 c$ & $0.26(0.31)$ & 0.36 & $0.52(0.44)$ & 0.25 & $0.53(0.39)$ & 0.38 & $0.55(0.55)$ & 0.37 \\
\hline$\Sigma$ MFA & 46.05 & 63.59 & 125.62 & 61.58 & 66.52 & 47.79 & 97.73 & 65.5 \\
\hline \multicolumn{9}{|c|}{ Polyunsaturated } \\
\hline $18: 2 \omega 6$ & $3.70(1.80)$ & 5.13 & $6.39(1.95)$ & 3.14 & $4.21(2.25)$ & 3.03 & $5.25(2.04)$ & 3.53 \\
\hline $18: 3 \omega 6$ & $0.04(0.08)$ & 0.05 & $0.95(0.95)$ & 0.47 & $0.61(0.62)$ & 0.44 & $0.98(0.63)$ & 0.66 \\
\hline $20: 4 \omega 6$ & $1.54(0.48)$ & 2.14 & $3.68(0.55)$ & 1.81 & $2.80(2.8)$ & 2.02 & $3.65(1.06)$ & 2.45 \\
\hline $20: 5 \omega 3$ & $3.33(1.04)$ & 4.62 & $7.36(1.62)$ & 3.62 & $4.22(1.88)$ & 3.04 & $6.48(2.46)$ & 4.35 \\
\hline $22: 5 \omega 6$ & $0.20(0.21)$ & 0.28 & $1.10(0.69)$ & 0.54 & $0.35(0.34)$ & 0.25 & $0.86(0.56)$ & 0.58 \\
\hline $22: 6 \omega 3$ & $2.68(0.89)$ & 3.72 & $6.03(2.14)$ & 2.97 & $2.86(1.18)$ & 2.06 & $4.3(1.91)$ & 2.89 \\
\hline$\Sigma \mathrm{PFA}$ & 11.49 & 15.94 & 25.52 & 12.56 & 15.06 & 10.84 & 21.52 & 14.46 \\
\hline \multicolumn{9}{|c|}{ Branched saturated } \\
\hline $\mathrm{i} 14: 0$ & $0.07(0.11)$ & 0.09 & $0.29(0.65)$ & 0.14 & $0.00(0.00)$ & 0.0 & $0.00(0.00)$ & 0.00 \\
\hline $\mathrm{i} 15: 0$ & $0.38(0.85)$ & 0.53 & $2.46(3.74)$ & 1.21 & $2.66(4.52)$ & 1.92 & $0.95(1.25)$ & 0.64 \\
\hline a15:0 & $0.47(0.91)$ & 0.65 & $2.91(4.42)$ & 1.43 & $1.38(1.67)$ & 0.99 & $0.90(1.54)$ & 0.6 \\
\hline $\mathrm{i} 16: 0$ & $0.13(0.29)$ & 0.18 & $1.23(0.99)$ & 0.61 & $0.39(0.29)$ & 0.28 & $0.92(0.82)$ & 0.62 \\
\hline $\mathrm{i} 17: 0$ & $0.21(0.39)$ & 0.29 & $1.20(0.38)$ & 0.59 & $0.20(0.27)$ & 0.14 & $0.70(0.49)$ & 0.47 \\
\hline a17:0 & $2.22(1.79)$ & 3.09 & $15.41(10.52)$ & 7.58 & $2.92(1.24)$ & 2.10 & $7.84(6.43)$ & 5.27 \\
\hline$\Sigma$ BSFA & 3.47 & 4.82 & 23.50 & 11.56 & 7.55 & 5.43 & 11.30 & 7.59 \\
\hline \multicolumn{9}{|l|}{ Cyclopropyl } \\
\hline cy17:0 & $2.54(5.46)$ & 3.52 & $1.66(2.29)$ & 0.82 & $16.13(35.73)$ & 11.61 & $0.64(0.65)$ & 0.43 \\
\hline cy19:0 & $3.07(5.91)$ & 4.26 & $1.52(1.10)$ & 0.80 & $24.88(43.47)$ & 17.91 & $1.36(0.56)$ & 0.91 \\
\hline$\Sigma \mathrm{Cy}$ & 5.61 & 7.78 & 3.28 & 1.62 & 41.01 & 29.52 & 2.0 & 1.34 \\
\hline \multicolumn{9}{|c|}{ Methyl-branched } \\
\hline 10me16:0 & $0.26(0.42)$ & 0.36 & $2.22(1.79)$ & 1.09 & $0.70(0.55)$ & 0.50 & $2.1(2.37)$ & 1.41 \\
\hline 10me18:0 & $0.07(0.16)$ & 0.1 & $0.46(0.27)$ & 0.22 & $0.15(0.15)$ & 0.11 & $0.40(0.30)$ & 0.27 \\
\hline ImeBSFA & 0.33 & 0.46 & 2.68 & 1.32 & 0.85 & 0.61 & 2.5 & 1.68 \\
\hline$\Sigma$ Total PLFA ${ }^{\mathrm{a}}$ & 72.08 & & 202.23 & & 138.90 & & 148.84 & \\
\hline \multicolumn{9}{|l|}{ Cy/MUFA } \\
\hline cy $17: 0 / 16: 1 \omega 7 \mathrm{c}$ & 0.41 & 0.06 & 1.57 & 0.04 & & & & \\
\hline cy19:0/18:1 $17 \mathrm{c}$ & 0.26 & 0.04 & 1.02 & 0.04 & & & & \\
\hline \multicolumn{9}{|l|}{ Trans/cis } \\
\hline $16: 1 \omega 7 \mathrm{t} / 16: 1 \omega 7 \mathrm{c}$ & 0.03 & 0.04 & 0.05 & 0.04 & & & & \\
\hline $18: 1 \omega 7 \mathrm{t} / 18: 1 \omega 7 \mathrm{c}$ & 0.02 & 0.03 & 0.03 & 0.03 & & & & \\
\hline
\end{tabular}


Table 2. Phospholipid fatty acid (PLFA) values presented as mol per unit area and as mol\% of total PLFA for burrow mimics from Expert 2. PLFA shown are the most abundant ( $>0.1 \mathrm{~mol} \%)$ fatty acids in the profiles. $\Sigma$ SFA: sum of saturated PLFA; $\Sigma M F A$ : sum of monounsaturated PLFA; $\Sigma$ PFA: sum of polyunsaturated PLFA; $\Sigma$ BSFA: sum of terminally branched saturated PLFA; $\Sigma$ Cy: sum of cyclopropyl PLFA; LmeBSFA: sum of methyl-branched saturated PLFA; Cy/MUFA: ratio of cyclopropyl PLFA to the MFA precursor; Trans/cis: ratio of trans to cis isomers of a given PLFA. Values are treatment means. Standard deviation in parentheses

\begin{tabular}{|c|c|c|c|c|c|c|c|c|}
\hline & \multicolumn{4}{|c|}{ Continuous irrigation } & \multicolumn{4}{|c|}{ Discontinuous irrigation } \\
\hline & $\begin{array}{l}2 \mathrm{wk} \\
\mathrm{pmol} \mathrm{cm}^{-2}\end{array}$ & $\overline{\mathrm{mol} \%}$ & $\begin{array}{l}6 \mathrm{wk} \\
\mathrm{pmol} \mathrm{cm}\end{array}$ & $\overline{\mathrm{mol} \%}$ & $\begin{array}{l}2 \mathrm{wk} \\
\mathrm{pmol} \mathrm{cm}\end{array}$ & $\overline{\mathrm{mol} \%}$ & $\frac{6 \mathrm{wk}}{\mathrm{pmol} \mathrm{cm}^{-2}}$ & $\mathrm{~mol} \%$ \\
\hline \multicolumn{9}{|l|}{ Saturated } \\
\hline $14: 0$ & $22.98(11.3)$ & 5.84 & $22.37(17.33)$ & 3.55 & $20.04(2.67)$ & 4.50 & $24.08(14.47)$ & 2.97 \\
\hline $15: 0$ & $9.36(3.38)$ & 2.38 & $10.90(5.83)$ & 1.73 & $10.41(4.36$ & 2.34 & $12.15(4.58)$ & 1.50 \\
\hline $16: 0$ & 79.83 (22.03) & 20.30 & 142.68 (84.69) & 22.66 & 77.07 (19.11) & 17.33 & 185.17 (62.57) & 22.82 \\
\hline $17: 0$ & $7.10(1.40)$ & 1.80 & $10.78(3.26)$ & 1.71 & $10.87(6.89)$ & 2.44 & $24.26(19.29)$ & 2.99 \\
\hline $18: 0$ & $11.56(3.53)$ & 2.94 & 31.09 (25.59) & 4.94 & $12.58(1.00)$ & 2.83 & $29.15(8.42)$ & 3.59 \\
\hline $20: 0$ & $1.07(1.52)$ & 0.27 & $7.42(2.02)$ & 1.18 & $0.87(1.23)$ & 0.20 & $7.85(5.26)$ & 0.97 \\
\hline$\Sigma$ SFA & 131.90 & 33.54 & 225.24 & 35.77 & 131.85 & 29.64 & 282.66 & 34.84 \\
\hline \multicolumn{9}{|c|}{ Monounsaturated } \\
\hline $16: 1 \omega 5 \mathrm{c}$ & $4.31(2.45)$ & 1.10 & $9.78(7.13)$ & 1.55 & $6.09(1.5)$ & 1.37 & $8.82(5.95)$ & 1.09 \\
\hline $16: 1 \omega 7 \mathrm{c}$ & 45.82 (14.09) & 11.65 & 70.35 (61.87) & 11.17 & 51.36 (21.63) & 11.55 & $73.32(30.27)$ & 9.04 \\
\hline $16: 1 \omega 7 \mathrm{t}$ & $2.97(1.92)$ & 0.76 & $3.58(2.06)$ & 0.57 & $2.71(0.9)$ & 0.61 & $5.28(4.69)$ & 0.65 \\
\hline $16: 1 \omega 9 \mathrm{c}$ & $6.07(0.76)$ & 1.54 & $19.85(13.94)$ & 3.15 & $5.44(1.74)$ & 1.22 & $43.96(38.04)$ & 5.42 \\
\hline $17: 1$ & $0.00(0.0)$ & 0.00 & $0.65(1.3)$ & 0.10 & $3.12(4.41)$ & 0.70 & 5.57 (3.89) & 0.69 \\
\hline i1 $7: 1 \omega 7 \mathrm{c}$ & $0.00(0.0)$ & 0.00 & $6.86(2.38)$ & 1.09 & $0.00(0.0)$ & 0.00 & $12.72(9.48)$ & 1.57 \\
\hline $18: 1 \omega 5 \mathrm{c}$ & $9.55(2.47)$ & 2.43 & $0.00(0.0)$ & 0.00 & $14.97(10.55)$ & 3.36 & $0.98(2.19)$ & 0.12 \\
\hline $18: 1 \omega 7 \mathrm{c}$ & $42.61(25.45)$ & 10.83 & $79.84(51.2)$ & 12.68 & $51.44(13.24)$ & 11.56 & 88.74 (34.05) & 10.93 \\
\hline $18: 1 \omega 7 \mathrm{t}$ & $1.77(2.51)$ & 0.45 & $0.96(1.91)$ & 0.15 & $0.00(0.0)$ & 0.00 & $1.27(1.77)$ & 0.16 \\
\hline $18: 1 \omega 9$ & $55.59(28.76)$ & 14.13 & 30.79 (15.96) & 4.89 & $61.43(1.39)$ & 13.81 & $39.49(13.72)$ & 4.87 \\
\hline $20: 1 \omega 9 c$ & $0.92(1.29)$ & 0.23 & $4.14(3.21)$ & 0.66 & $2.21(0.51)$ & 0.50 & $4.42(2.56)$ & 0.54 \\
\hline$\Sigma \mathrm{MFA}$ & 169.61 & 43.12 & 226.80 & 36.03 & 198.76 & 44.68 & 284.57 & 35.08 \\
\hline \multicolumn{9}{|c|}{ Polyunsaturated } \\
\hline $18: 2 \omega 6$ & $6.63(9.38)$ & 1.69 & $2.11(2.45)$ & 0.34 & $2.59(3.66)$ & 0.58 & $4.03(3.11)$ & 0.50 \\
\hline $18: 3 \omega 3$ & $0.00(0.0)$ & 0.00 & $3.67(3.24)$ & 0.58 & $0.83(1.18)$ & 0.19 & $2.17(2.02)$ & 0.27 \\
\hline $18: 3 \omega 6$ & $4.50(1.03)$ & 1.14 & $3.92(3.1)$ & 0.62 & $0.0(0.0)$ & 0.00 & $5.43(3.73)$ & 0.67 \\
\hline $20: 4 \omega 6$ & $2.98(1.67)$ & 0.76 & $2.15(2.49)$ & 0.34 & $7.04(6.62)$ & 1.58 & $3.24(4.49)$ & 0.40 \\
\hline $20: 5 \omega 3$ & $3.16(0.8)$ & 0.80 & $0.81(1.61)$ & 0.13 & $1.01(1.43)$ & 0.23 & $3.13(6.33)$ & 0.39 \\
\hline $22: 5 \omega 5$ & $1.03(1.45)$ & 0.26 & $1.48(1.73)$ & 0.24 & $1.53(2.17)$ & 0.34 & $0.85(1.7)$ & 0.10 \\
\hline $22: 6 \omega 3$ & $0.99(1.4)$ & 0.25 & $0.30(0.59)$ & 0.05 & $1.03(1.45)$ & 0.23 & $1.36(2.28)$ & 0.17 \\
\hline$\Sigma \mathrm{PFA}$ & 19.29 & 4.90 & 14.44 & 2.29 & 14.03 & 3.15 & 20.21 & 2.50 \\
\hline \multicolumn{9}{|c|}{ Branched saturated } \\
\hline $\mathrm{i} 14: 0$ & $2.61(0.43)$ & 0.66 & $0.81(1.61)$ & 0.13 & $5.44(1.7)$ & 1.22 & $3.50(5.01)$ & 0.43 \\
\hline i15:0 & $17.91(8.36)$ & 4.55 & 34.85 (25.81) & 5.54 & $17.67(5.02)$ & 3.97 & $48.98(27.88)$ & 6.04 \\
\hline a15:0 & $7.34(2.35)$ & 1.87 & $14.00(9.93)$ & 2.22 & $7.28(0.42)$ & 1.64 & 22.35 (16.66) & 2.75 \\
\hline i16:0 & $5.79(2.59)$ & 1.47 & $13.47(8.6)$ & 2.14 & $5.75(1.35)$ & 1.29 & $16.78(6.64)$ & 2.07 \\
\hline i17:0 & $2.84(0.54)$ & 0.72 & $11.42(5.59)$ & 1.81 & $2.82(0.81)$ & 0.63 & $12.24(3.7)$ & 1.51 \\
\hline a17:0 & $8.25(3.33)$ & 2.10 & $11.40(6.54)$ & 1.81 & $10.58(3.1)$ & 2.38 & $13.84(3.14)$ & 1.71 \\
\hline$\Sigma$ BSFA & 44.74 & 11.37 & 85.95 & 13.65 & 49.52 & 11.13 & 117.69 & 14.51 \\
\hline \multicolumn{9}{|l|}{ Cyclopropyl } \\
\hline cy $17: 0$ & $9.69(1.92)$ & 2.46 & $16.63(10.93)$ & 2.64 & $5.4(0.58)$ & 1.21 & $14.68(0.57)$ & 1.81 \\
\hline cy19:0 & $3.12(0.54)$ & 0.79 & $25.40(10.12)$ & 4.03 & 29.07 (36.29) & 6.54 & 39.49 (31.51) & 4.87 \\
\hline$\Sigma \mathrm{Cy}$ & 12.81 & 3.25 & 42.03 & 6.67 & 34.47 & 7.75 & 54.17 & 6.68 \\
\hline \multicolumn{9}{|c|}{ Methyl-branched } \\
\hline 10me16:0 & $3.38(0.54)$ & 0.86 & $17.07(9.76)$ & 2.71 & $3.95(1.08)$ & 2.42 & $20.50(7.48)$ & 2.53 \\
\hline 10me18:0 & $0.00(0.0)$ & 0.00 & $0.00(0.0)$ & 0.00 & $0.00(0.00)$ & 0.00 & $2.12(4.11)$ & 0.26 \\
\hline 12me18:0 & $0.00(0.0)$ & 0.00 & $8.65(3.87)$ & 1.37 & $0.00(0.00)$ & 1.12 & $8.30(3.01)$ & 1.02 \\
\hline br19 & $11.56(1.83)$ & 2.94 & $9.40(7.41)$ & 1.49 & $12.28(3.75)$ & 1.73 & $21.32(7.52)$ & 2.63 \\
\hline ImeBSFA & 14.94 & 3.80 & 35.12 & 5.57 & 16.23 & 5.27 & 52.24 & 6.44 \\
\hline$\Sigma$ Total PLFA & 393.29 & & 629.58 & & 444.87 & & 811.54 & \\
\hline \multicolumn{9}{|l|}{ Cy/MUFA } \\
\hline 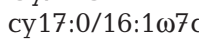 & C $\quad 0.21$ & & 0.24 & & 0.11 & & 0.20 & \\
\hline 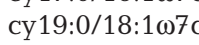 & C $\quad 0.07$ & & 0.32 & & 0.57 & & 0.44 & \\
\hline \multicolumn{9}{|l|}{ Trans/cis } \\
\hline $16: 1 \mathrm{w} 7 \mathrm{t} / 16: 1 \omega 7$ & $7 \mathrm{C} \quad 0.06$ & & 0.05 & & 0.05 & & 0.07 & \\
\hline $18: 1 \mathrm{w} 7 \mathrm{t} / 18: 1 \omega 7$ & ${ }_{\text {7 }} 0.04$ & & 0.01 & & 0.00 & & 0.01 & \\
\hline
\end{tabular}


found in natural burrow systems, include branched saturated, methyl-branched and cyclopropyl PLFAs (Tables 1 \& 2, Fig. 4A,B).

\section{Effects of tube composition and irrigation frequency}

The burrow mimic microbial communities were responsive to experimental manipulations, and several of these responses illuminated fundamental controls on community composition by properties of the burrow microenvironment. In Expt 1 (effects of irrigation and tube composition), pre-coating the burrow mimics with the bacterial exopolysaccharide Gelrite appeared to limit bacterial growth during short-term incubations (Fig. 5), regardless of irrigation frequency. ANOVAs for the selected PLFAs showed no significant differences as a function of irrigation frequency or tube composition at the 0.013 level. However, a number of PLFAs showed a general trend of higher concentrations in uncoated tubes (Fig. 5). These results may indicate failure of some bacterial species to successfully colonize the bacterial exopolymer or failure of colonists to survive and proliferate on this surface perhaps due to a decrease in available surface area, irrespective of irrigation frequency.

Production of cy17:0 and cy19:0 has been interpreted as an indicator of stress and/or growth at oxic/anoxic interfaces (Guckert et al. 1985), but neither of these conditions were suggested in the burrow mimic treatments. In the discontinuous irrigation treatments, ratios of the cyclopropyl fatty acids to their precursors $(16: 1 \omega 7 \mathrm{c}$ and $18: 1 \omega 7 \mathrm{C}$ respectively) were 1.57 and 1.02 for coated mimics and 0.04 and 0.04 for uncoated mimics. The ratios observed for uncoated mimics correspond closely to those found in natural burrows and tubes while the ratios from coated mimics were more similar to those of anoxic bulk sediments (Steward et al. 1996). This suggests that the reduced microbial biomass in the coated tubes may have been related to small populations of slower-growing anaerobes. High trans to cis ratios (>0.1) for $16: 1 \omega 7$ and $18: 1 \omega 7 \mathrm{C}$ have also been cited as evidence for physiological stress, but these ratios were $\leq 0.05$ for all treatments. These ratios suggest that the biofilm populations were not stressed and that the uncoated mimics provided the most realistic analog to natural burrows and tubes.

We conducted a multivariate cluster analysis to determine the degree of relatedness among the fatty acids represented in the burrow mimics and to assess whether the resulting clusters corresponded to the experimental manipulations. This analysis was based

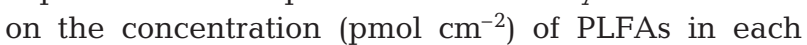
burrow mimic and not mole percent. The grouping of mimics and the linkage distances tended to reflect the

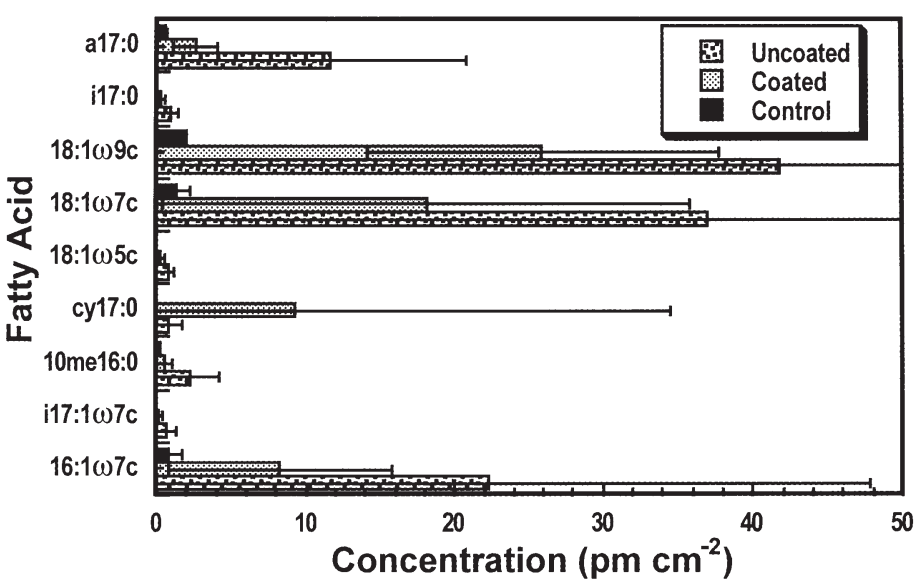

Fig. 5. Concentrations of 9 fatty acids, chosen for either high biomass or previously reported linkages with sulfate reducers, in burrow mimic biofilms as a function of tube composition (uncoated, coated and control) in Expt 1. Uncoated mimics tended to have higher concentrations than coated mimics. Controls are essentially 'blanks', i.e. the resident phospholipid fatty acids signature on the nylon membrane prior to embedding it in sediment

presence or absence of a coating, and little effect of irrigation frequency (Fig. 6). This is consistent with the trend of higher microbial biomass in uncoated burrow mimics. Clearly, the dominant factor driving the bacterial fatty acid profile was the presence or absence of a coating.

\section{Effects of residence time and irrigation frequency}

Expt 2 examined the effects of incubation time and irrigation frequency on the development of the burrow biofilm microbial community. This experiment employed sandier sediment than Expt 1 and took place over a longer period of time. There was generally higher microbial PLFA biomass in the $6 \mathrm{wk}$ incubation mimics relative to the $2 \mathrm{wk}$ incubation mimics (Table 2), although the distribution of the various fatty acid classes was similar among experimental treatments. Changes in community composition were indicated by shifts in the PLFA profile with experimental manipulation, although only 1 PLFA selected for ANOVA, 10me16, showed a significant difference as a function of residence time at the 0.013 level. PLFA composition appeared to undergo a succession from a primary biofilm dominated by early colonists to a more mature community dominated by persistent secondary colonists (Fig. 7, Table 2). The branched PLFAs 10me16:0 and i17:0, and the monounsaturated PLFAs i17:1 $107 \mathrm{c}$, and $18: 1 \omega 7 \mathrm{c}$ generally increased over the incubation period. The monounsaturated PLFAs, $18: 1 \omega 5 \mathrm{c}$ and $18: 1 \omega 9$ decreased in concentration with 

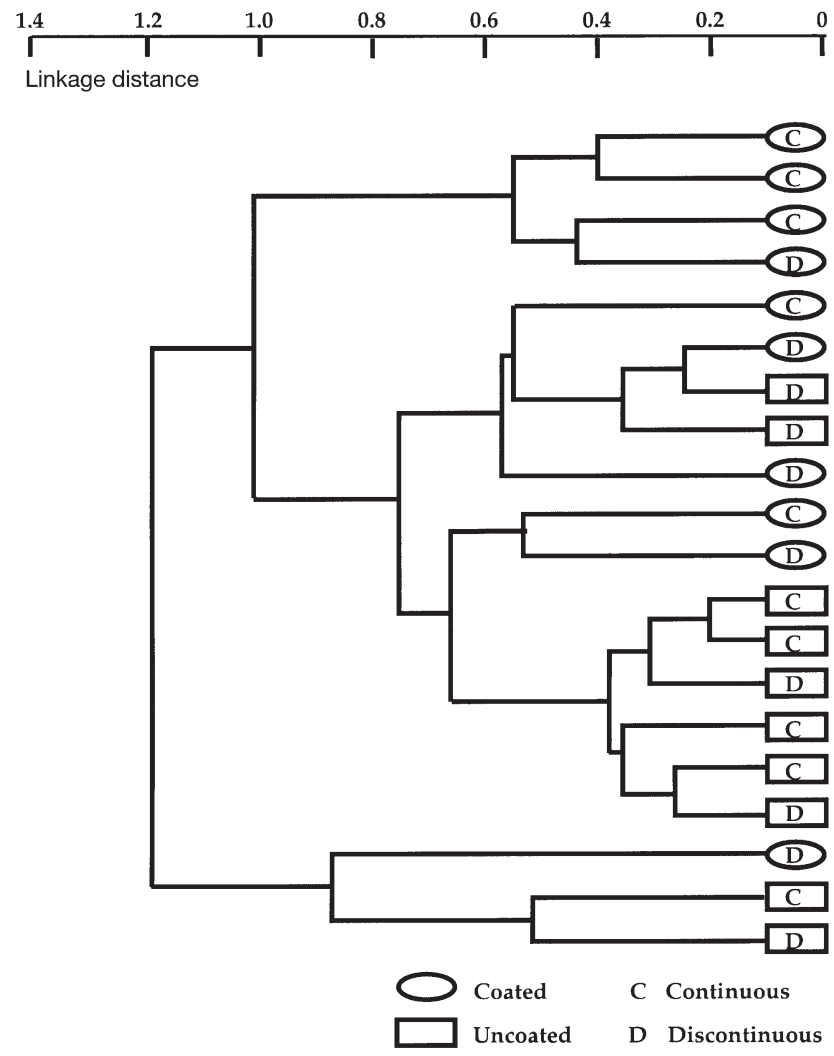

Fig. 6. Results of cluster analysis for burrow mimics in Expt 1. Similarity in phospholipid fatty acids (PLFA) signatures was reflected primarily in tube composition, with uncoated and coated tubes forming clusters. Irrigation frequency did not exert a strong influence on PLFA signature, as indicated by the absence of distinct clustering of the irrigation treatment

the longer incubation period. The overall results indicate the development of a mature biofilm community, with greater representation of anaerobic bacteria (e.g. i17:0, cy17, 10me16:0; Findlay \& Dobbs 1993), from the initial ( $2 \mathrm{wk}$ ) biofilm. The apparent inhibition of at least some anaerobes (e.g. cy19, 10me16) in primary biofilms by continuous irrigation seemed to decrease with further biofilm development, with no apparent differences in anaerobe PLFAs between irrigation treatments in mature biofilms. This may indicate proliferation of more oxygen tolerant anaerobe species, rapid depletion of oxygen by aerobic species or the presence of reduced microzones within the mature biofilm.

The cluster analysis for the results of Expt 2 is consistent with the trends discussed above, showing clustering and closer linkage distances as a function of tube residence time in sediments (Fig. 8). In general, tubes having longer residence time were more closely related, relative to those having a shorter tenure in the sediment cores. The similarity among the clusters

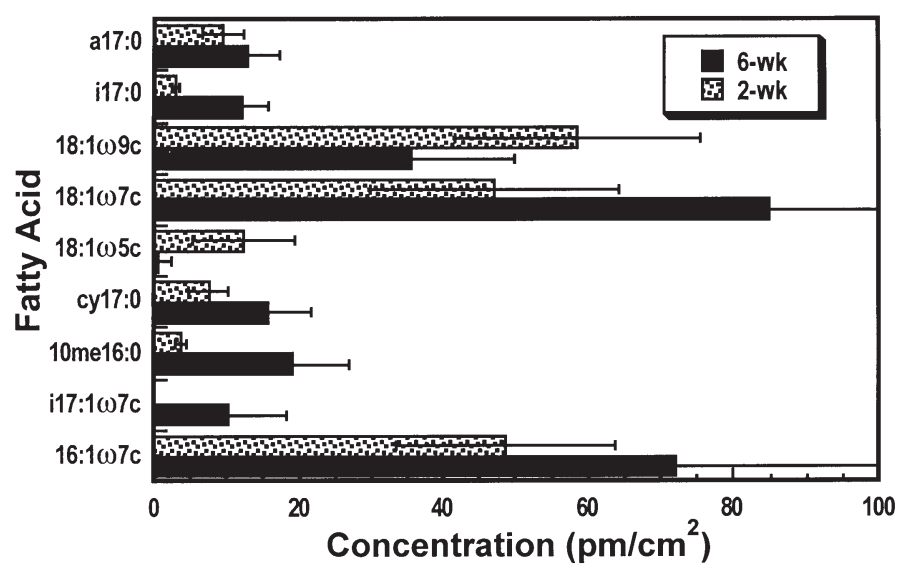

Fig. 7. Concentrations of 9 fatty acids, chosen for either high biomass or previously reported linkages with sulfate reducers, in burrow mimic biofilms as a function of tube residence time ( 2 wk vs 6 wk), In general, higher concentrations were found in ' $6 \mathrm{wk}^{\text {' sam- }}$ ples, generally due to the longer residence time and accumulation of microbial biomass

tended to reflect the degree of development and maturity of the biofilm. As in the previous experiment, there was little apparent influence of irrigation frequency on the PLFA signature of the biofilm microorganisms.

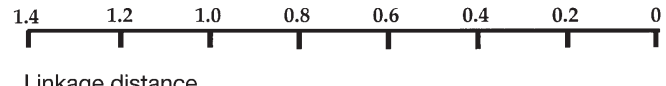

Linkage distance

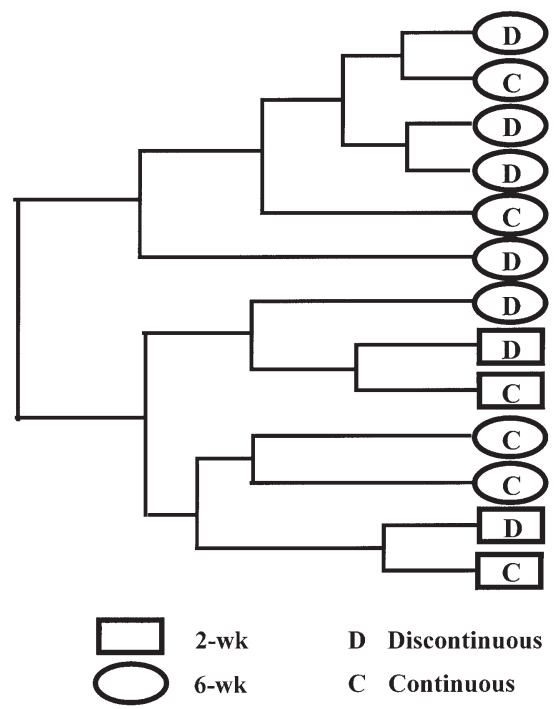

Fig. 8. Results of cluster analysis for burrow mimics in Expt 2. Similarity in phospholipid fatty acids (PLFA) signatures was reflected primarily in tube residence time, with 2 and 6 wk tubes forming clusters. Irrigation frequency did not exert a strong influence on PLFA signature, as indicated by the absence of clusters above 


\section{DISCUSSION}

Burrows and tubes of infauna are dynamic systems that support complex microbial assemblages and promote striking gradients in biological and geochemical properties over small spatial scales. These properties give rise to unique microhabitats with rapid rates of elemental cycling and correspondingly, high fluxes of materials through the burrow system. Consequently, they promote significant heterogeneity in the ecological and geochemical properties of benthic systems. To gain insight into the processes that structure these complex systems, it is important to identify the physical, chemical and biological variables that shape the burrow microbial community structure and diversity, and determine the ecological and geochemical functions the microbiota perform in sedimentary systems.

Results from our experiments both confirm the findings of previous researchers and extend our understanding of the factors that influence the development and character of microbial communities in sedimentary systems. The data suggest that the composition of the tube (i.e. the physicochemical properties) can affect both the sequence and rate of colonization in the burrow biofilm. Tubes that were coated with a bacterial exopolymer exhibited lower biomass and a somewhat different PLFA signature relative to uncoated tubes (Table 1, Fig. 6). It is unclear whether the apparent inhibition of colonization in coated tubes was due to the chemical composition of the coating substance or physical alteration of the surface, or perhaps both factors.

Our results also suggest that the residence time of tubes in sediments impacts the biomass and successional dynamics of microorganisms in burrow systems. Tubes that had shorter $(2 \mathrm{wk})$ residence times in sediments were characterized by lower microbial biomass and by PLFA signatures that were indicative of an assemblage containing lower proportions of anaerobic bacteria. As the experiment progressed and tubes resided in sediments for a longer period of time, the associated biofilms acquired higher microbial biomass and also a distinct anoxic character, as indicated by the higher quantities of cy17, 10me16:0 and i17:1 $107 \mathrm{c}$; all of which compounds are associated with sulfatereducing bacteria. The vast majority of infauna is 'discretely motile', relocating and building new tubes or burrows periodically, with the frequency of movement driven by a variety of factors, e.g. food limitation, the presence of competitors or other environmental factors. Our data suggest that the frequency of tube movement could have strong implications for the bacterial character and biogeochemical activity associated with actively maintained infaunal tubes. Abandoned tubes may be passively irrigated, perhaps maintaining a similar chemical signature to an actively irrigated burrow (e.g. Ray \& Aller 1985), or infilled and undergo significant degradation (Kristensen et al. 1991a). We would expect that associated biofilms would have a distinctly different character under these 2 scenarios.

The evidence presented above suggests that infaunal behavior, as the controller of tube composition and tube residence time, influences the microbial and biogeochemical dynamics within burrows. However, the behavior of irrigation frequency was not a substantial driver of the PLFA signature within the burrow biofilm. In Expt 1, tubes were embedded in sediments for a relatively short period of time and at lower seawater temperatures than in Expt 2. This combination of factors may not have allowed the full developmental sequence forming a mature biofilm to be completed or the effect of irrigation behavior to manifest. In Expt 2, irrigation effects were allowed to develop for a longer period of time and temperatures were higher than in the Expt 1, but the irrigation frequency did not emerge as an important factor structuring the bacterial assemblage as indicated by PLFA analysis (Figs. 6 \& 8). The absence of a large irrigation effect could result from rapid utilization of oxygen by the surficial layer of microorganisms (i.e. those most closely in contact with burrow water) such that subsurface microorganisms experienced negligible fluctuations in oxygen concentrations. It may also result from the establishment of persistent microzones where anaerobic activity thrived in spite of the availability of oxygen associated with continuous irrigation. It is noteworthy that bacterial cell numbers at different locations in biofilms lining the tubes of the onuphid polychaete Diopatra cuprea did not significantly differ, in spite of substantial differences in their proximity to the source of the irrigation activity, the polychaete itself (Phillips \& Lovell 1999). More detailed analysis of the structure and layering of biofilms may help determine why the irrigation-driven supply of oxidants (and removal of metabolites) had relatively little impact on bacterial phospholipid signatures.

Finally, we did not explicitly examine the extent to which infaunal exudates (e.g. mucous, secondary compounds) affect the burrow microbial community. However, we suspect that this component could also impact microbial populations and activities in burrows and tubes provided by infaunal hosts. Certainly the presence of a bacterial exopolymer greatly altered the extent and nature of colonization in Expt 1. Based on this evidence, the composition of polysaccharide exudates may be a very important control mechanism influencing the successional sequence(s) involved in formation of the mature biofilm community. It is also the case that some polychaete secondary metabolites, such as bromophenols, can inhibit activity and pre- 
sumably growth of certain specific bacterial groups (Giray \& King 1997), although no pervasive effect of these compounds is apparent (Steward et al. 1992, 1996, Lovell et al. 1999).

We have shown that burrow systems can be mimicked in laboratory environments, as indicated by the similarity of physical characteristics between the artificially constructed tubes and their natural analogs, and the similarity of PLFA signatures between the microorganisms of the artificial burrow systems and those quantified in natural systems (Dobbs \& Guckert 1988a, Steward et al. 1996). Our results suggest that behavioral aspects of infaunal organisms, such as the composition of the tube and the frequencies at which tubes are constructed, influence microbial abundance and diversity within biofilms. These factors may explain, in part, the biogeochemical heterogeneity associated with animal burrows in natural systems. An important 'next step' is to assess rates of biogeochemical processes in conjunction with biomass estimates and PLFA signatures in the biofilms of natural burrows. Such an effort would assess the degree of connection between PLFA biomass and elemental cycles in natural systems, and provide further insights into the dynamic and complex systems presented by nearshore sedimentary environments.

Acknowledgements. This research was supported by NSF grants OCE 9314681 and OCE 9629596 to RLM and OCE9201857 to CRL.

\section{LITERATURE CITED}

Aller JY, Aller RC (1986) Evidence for localized enhancement of biological activity associated with tube and burrow structures in deep-sea sediments and the HEBBLE site, western North Atlantic. Deep-Sea Res 33:755-790

Aller RC (1980) Quantifying solute distributions in the bioturbated zone of marine sediments by defining an average microenvironment. Geochim Cosmochim Acta 44: 1955-1965

Aller RC (1983) The importance of the diffusive permeability of animal burrow linings in determining marine sediment chemistry. J Mar Res 41:299-322

Aller RC, Yingst JY (1978) Biogeochemistry of tube-dwellings: a study of the sedentary polychaete Amphitrite ornata (Leidy). J Mar Res 36:201-254

Aller RC, Yingst JY (1985) Effects of the marine depositfeeders Heteromastus filiformis (Polychaeta), Macoma balthica (Bivalvia), and Tellina texana (Bivalvia) on averaged sedimentary solute transport, reaction rates and microbial distributions. J Mar Res 43:615-645

Aller RC, Yingst JY, Ullman WJ (1983) Comparative biogeochemistry of water in intertidal Onuphis (polychaeta) and Upogebia (crustacea) burrows: temporal patterns and causes. J Mar Res 41:571-604

Bligh EG, Dyer WJ (1959) A rapid method of total lipid extraction and purification. Can J Biochem Physiol 37:911-917

Boudreau BP, Marinelli RL (1994) A modelling study of discontinuous biological irrigation. J Mar Res 52:947-968
Dobbs FC, Guckert JB (1988a) Callianassa trilobata (Crustacea: Thalassinidae) influences abundance of meiofauna and biomass, composition and physiologic state of microbial communities within its burrow. Mar Ecol Prog Ser 45: 69-79

Dobbs FC, Guckert JB (1988b) Microbial food resources of the macrofaunal-deposit feeder Ptychodera bahamensis (Hemichordata: Enteropneusta). Mar Ecol Prog Ser 45:127-136

Fauchald K, Jumars PA (1979) The diet of worms: a study of polychaete feeding guilds. Oceanogr Mar Biol Annu Rev 17:193-284

Federle TW, Dobbins DC, Thornton-Manning JR, Jones DD (1986) Microbial biomass, activity, and community structure in subsurface soils. Ground Water 24:365-374

Fenchel T (1996) Worm burrows and oxic microniches in marine sediments. 2. Distribution patterns of ciliated protozoa. Mar Biol 127:297-301

Findlay RH, Dobbs FC (1993) Quantitative description of microbial communities using lipid analysis. In: Kemp PF, Sherr BF, Sherr EB, Cole JJ (eds) Handbook of methods in aquatic microbial ecology. Lewis Publishers, Boca Raton, FL, p 271-284

Findlay RH, White DC (1983) The effects of feeding by the sand dollar Mellita quinquiesperforata (Leske) on the benthic microbial community. J Exp Mar Biol Ecol 72:25-41

Findlay RH, Trexler MB, Guckert JB, White DC (1990) Laboratory study of disturbance in marine sediments: response of a microbial community. Mar Ecol Prog Ser 62:121-133

Forster S, Graf G (1992) Continuously measured changes in redox potential influenced by oxygen penetrating from burrows of Callianassa subterranea. Hydrobiologia 235/ 236:527-532

Forster S, Graf G (1995) Impact of irrigation on oxygen flux into the sediment: intermittent pumping by Callianassa subterranea and 'piston-pumping' by Lanice conchilega. Mar Biol 123:335-346

Giray C, King GM (1997) Effect of naturally occurring bromophenols on sulfate reduction and ammonia oxidation in intertidal sediments. Aquat Microbial Ecol 13:295-301

Guckert JB, Antworth CP, Nichols PD, White DC (1985) Phospholipid, ester-linked fatty acid profiles as reproducible assays for changes in prokaryotic community structure of estuarine sediments. Microbiol Ecol 31:147-158

Haak SK, Gachow H, Odelson DA, Forney LJ, Klug MJ (1994) Accuracy, reproducibility and interpretation of fatty acid methyl ester profiles of model bacterial communities. Appl Environ Microbiol 60:2483-2493

Huttel M (1990) Influence of the lugworm Arenicola marina on porewater nutrient profiles of sand flat sediments. Mar Ecol 62:241-248

Jensen P, Emrich R, Weber K (1992) Brominated metabolites and reduced numbers of meiofauna organisms in the burrow wall lining of the deep-sea enteropneust Stereobalanus canadensis. Deep-Sea Res I 39:1247-1253

King GM (1986) Inhibition of microbial activity in marine sediments by a bromophenol from a hemichordate. Nature 323:257-259

Krager CD, Woodin SA (1993) Spatial persistence and sediment disturbance of an arenicolid polychaete. Limnol Oceanogr 38:509-520

Kristensen E (1983) Ventilation and oxygen uptake by three species of Nereis (Annelida: Polychaeta). I. Effects of hypoxia. Mar Ecol Prog Ser 12:289-297

Kristensen E (1984) Effect of natural concentrations on nutrient exchange between a polychaete burrow in estuarine sediment and the overlying water. J Exp Mar Biol Ecol 75: $171-190$ 
Kristensen E, Jensen MH, Andersen TK (1985) The impact of the polychaete Nereis virens (sars) burrows on nitrification and nitrate reduction in estuarine sediments. J Exp Mar Biol Ecol 85:75-91

Kristensen E, Aller RC, Aller JY (1991a) Oxic and anoxic decomposition of tubes from te burrowing sea anemone Ceriantheopsis americanus: implications for bulk sediment carbon and nitrogen balance. J Mar Res 49:589-617

Kristensen E, Jensen MH, Aller RC (1991b) Direct measurement of dissolved inorganic nitrogen exchange and denitrification in individual polychaete (Nereis virens) burrows. J Mar Res 49:355-377

Lovell CR, Steward CC, Phillips TM (1999) Activity of marine sediment bacterial communities exposed to 4-bromophenol, a polychaete secondary metabolite. Mar Ecol Prog Ser 179:241-246

Mangum CP (1964) Activity patterns in metabolism and ecology of polychaetes. Comp Biochem Physiol 11:239-256

Marinelli RL (1992) Effects of polychaetes on silicate dynamics and fluxes in sediments: importance of species, animal activity and polychaete effects on benthic diatoms. J Mar Res 50:745-779

Marinelli RL (1994) Effects of burrow ventilation on activities of a terebellid polychaete and silicate removal from sediment porewaters. Limnol Oceanogr 39:303-317

Marinelli RL, Boudreau BP (1996) An experimental and modelling study of $\mathrm{pH}$ and related solutes in an irrigated, anoxic coastal sediment. J Mar Res 54:939-966

Martin WR, Banta GT (1992) The measurement of sediment irrigation rates: a comparison of the Br-tracer and 222Rn/ 226Ra disequilibrium techniques. J Mar Res 50:125-154

Mayer MS, Schaffner L, Kemp WM (1995) Nitrification potentials of benthic macrofaunal tubes and burrow walls: effects of sediment $\mathrm{NH}_{4}{ }^{+}$and animal irrigation behavior. Mar Ecol Prog Ser 121:157-169

Meyers MB, Powell EN, Fossing H (1987) Microdistribution of interstitial meiofauna, oxygen and sulfide gradients, and the tubes of macroinfauna. Mar Ecol Prog Ser 35:233-241

Meyers MB, Powell EN, Fossing H (1988) Movement of oxybiotic and thiobiotic meiofauna in response to changes in porewater oxygen and sulfide gradients around macroinfaunal tubes. Mar Biol 98:395-414

Nichols PD, Palmisano AC, Smith GA, White DC (1986) Lipids of the antarctic sea ice diatom Nitschia cylindrus. Phytochemistry 25:1649-1653

Phillips TM, Lovell CR (1999) Distributions of total and active bacteria in biofilms lining tubes of the onuphid polychate Diopatra cuprea. Mar Ecol Prog Ser 183:169-178

Rajendran N, Matsuda O, Imamura N, Urushigawa Y (1992) Variation in microbial biomass and community structure in sediments of eutrophic bays as determined by phospholipid ester-linked fatty acids. Appl Environ Microbiol 58: 562-571

Ray AJ, Aller RC (1985) Physical irrigation of relict burrows: implications for sediment chemistry. Mar Geol 62:371-379

Schottler U, Weinhausen G, Zebe E (1983) The mode of energy production in the lugworm Arenicola marina at different oxygen concentrations. J Comp Physiol 149B:547-555

Editorial responsibility: Kenneth Tenore (Contributing Editor), Solomons, Maryland, USA
Scott DM (1976) Circadian rhythm of anaerobiasis in a polychaete annelid. Nature 226:811-813

Smith GA, Nichols PD, White DC (1986) Fatty acid composition and microbial activity of benthic marine sediment from McMurdo Sound, Antarctica. FEMS Microbiol Ecol $38: 219-231$

Steward CC, Pinckney J, Piceno Y, Lovell CR (1992) Bacterial numbers and activity, microalgal biomass and productivity, and meiofaunal distribution in sediments naturally contaminated with biogenic bromophenols. Mar Ecol Prog Ser 90:61-71

Steward CC, Nold SC, White DC, Lovell CR (1996) Microbial biomass and community structures in the burrows of bromophenol-producing and non-producing marine worms and surrounding sediments. Mar Ecol Prog Ser 133:149-165

Tunlid A, White DC (1992) Biochemical analysis of biomass, community structure, nutritional status and metabolic activity of microbial communities in soil. In: Stotsky $\mathrm{G}_{\text {, }}$ Bollag JM (eds) Soil biochemistry. Marcel Dekker, New York, p 229-262

Vainshtein M, Hippe H, Kroppenstedt RM (1992) Cellular fatty acid composition of Desulfovibrio species and its use in classification of sulfate-reducing bacteria. Syst Appl Microbiol 15:554-566

Vestal RJ, White DC (1992) Lipid analysis in microbial ecology: quantitative approaches to the study of microbial communities. BioScience 39:535-541

Wells GP (1949) Respiratory movements of Arenicola marina L.: intermittent irrigation of the tube, and intermittent aerial respiration. J Mar Biol Assoc UK 28:447-464

Wells GP, Dales RP (1951) Spontaneous activity patterns in animal behaviour: the irrigation of the burrow in the polychaetes Chaetopterus variopedatus Renier and Neries diversicolor O.F. Muller. J Mar Biol Assoc UK 29:661-680

White DC (1983) Analysis of microorganisms in terms of quantity and activity in natural environments. In: Slater JH, Whittenbury R, Wimpenny JWT (eds) Microbes in their natural environments. Symp Society of General Microbiology. Cambridge Univ Press, Cambridge, p 37-66

White DC (1988) Validation of quantitative analysis for microbial biomass, community structure and metabolic activity. Arch Hydrobiol 31:1-18

Woodin SA (1982) Browsing: important in marine sedimentary environments? Spionid polychaete examples. J Exp Mar Biol Ecol 60:35-65

Woodin SA (1984) Effects of browsing predators: activity changes in infauna following tissue loss. Biol Bull 166: $558-573$

Woodin SA, Marinelli RL (1991) Biogenic habitat modification in marine sediments: the importance of species composition and activity. Symp Zool Soc Lond 63:231-250

Woodin SA, Walla MD, Lincoln DE (1987) Occurrence of brominated compounds in soft-bottom benthic organisms. J Exp Mar Biol Ecol 107:209-217

Woodin SA, Marinelli RL, Lincoln DE (1993) Allelochemical inhibition of recruitment in sedimentary assemblages. J Chem Ecol 19:517-530

Submitted: December 4, 2000; Accepted: January 14, 2002 Proofs received from author(s): May 13, 2002 